\title{
THE EFFECT OF DEMONETIZATION ON PAYMENT SYSTEM: A REVIEW
}

\author{
SREEJITH. R. K.
}

Assistant Professor, Department of Management Studies

Vigyaan College of Applied Sciences, Kattakada, Thiruvananthapuram, India

This article mainly focuses on the impact that Demonetization has had on the various payment methods in India. Demonetisation keeps digital payments up; cashless transactions grow 13.5\% in September. As per RBI reports, digital transactions have grown 13.5 per cent from Rs 109.82 trillion in August to Rs 124.69 trillion in September; the highest was in March at Rs 149.59 trillion. In the year after demonetisation, digital transactions have grown considerably. With digital wallets, quick response (QR) codes, near field communication (NFC) technology, sound wave systems, virtual cards, unified payment interface (UPI) and Aadhaar Pay offering top-notch secure payment options, the smart phone has become the most sought after all-in-one device. Government and the RBI are continuously exploring cashless payments across the country. This paper explores the effect of demonetization on payment system in the Indian economy. It aims to see how the various digital platforms have evolved with the advent of demonetization. This study also gives an insight in to the effects of demonetization, the positive and negative impacts in the Indian economy. Demonetisation for a short term may be negative but in long term it may be very positive for the growth of e-commerce industry and also it removes the corrupt practice of generating black money with otherwise is not possible in the case of digital payment system.

KEYWORDS: Demonetization, Digital Payment, Digital Platforms, Cashless Transactions, E-Commerce \& Indian Economy
\end{abstract}

Received: Nov 20 2018; Accepted: Dec 10, 2018; Published: Jan 02, 2019; Paper Id.: IJAFMRJUN20191

\section{INTRODUCTION}

Demonetisation is an act of cancelling the legal tender status of a currency unit in circulation. Anticipating positive changes in the liquidity structure as whole, nations often adopt the Demonetisation policy as a measure to counterbalance the current economic condition. Countries across the globe have used Demonetisation at some point or the other to control situations such as inflation and to boost the economy. On $8^{\text {th }}$ November 2016, on a Tuesday evening, through a 40-minute-long speech Prime Minister Narendra Modi announced the demonetization of existing notes of Rs 500 and Rs 1000 during a televised address. PM announced that the notes of Rs 500 and Rs 1000 "will not be legal tender from midnight tonight" and these will be "just worthless pieces of paper". PM also urged people to "join this mahayajna against the ills of corruption, curb counterfeiting and money laundering. This move has been criticised as poorly planned and unfair, and was met with strikes against the government in several places across India. The government believes that this currency ban is required to control inflation, to fight against corruption, to remove counterfeit currency, and to discourage the cash transactions. The severe cash crunch in the economy after demonetisation has forced people to use the available digital payment options. The cashless transactions in the country surged to the highest level after demonetisation. Now the business environment is totally changed because of the information technology advancement, it also adopted IT techniques and its application for doing their business. Now online purchasing and sales through the internet are very common. 
"Business activities conducted using E-commerce is an activity and process by which online sales, purchase, information collection and make and collect payment for business purpose are done. The purpose of this paper is to theoretically as well as empirically assess the impact and effect of demonetisation on the payment system in Indian economy.

\section{OBJECTIVES OF THE STUDY}

- To understand the meaning and reasons of demonetisation.

- $\quad$ To know the position of cash transactions and cashless payments in India.

- $\quad$ To assess the factor effect on e-commerce after Demonetisation.

- $\quad$ To examine the payment habits among customer after demonetisation.

\section{DEMONETISATION ON INDIAN ECONOMY}

In a country where $85 \%$ of transactions take place by cash, cancelling the legal tender character of two high denomination banknotes raises a lot of questions. The service sector in the country that depends mostly on cash transactions will be adversely hit because of Demonetisation. Not to mention, the consumption activity of India has come to a screeching halt. This drop in economic activity could last for a few months and as a result, GDP could fall significantly from the previous year's values.

Even as the country faces the greatest financial crunch of all times, some analysts predict the economic conditions to stabilize in a few quarters. Deutsche bank and Goldman Sachs expect India to join the list of the fastest growing economies by next fiscal year. An improved monsoon season in 2017 can favour agricultural economy of the nation, which in turn will add to the financial recovery as a whole. Economists also predict that the decision to scrap high-value currency notes will lead to GDP growth by $2 \%$.

\section{DEMONETIZATION HISTORY}

First time demonetization was effected in India was when Rs1,000, Rs5,000, and Rs10,000 notes were taken out of circulation in January 1946, a year and a half before the country won independence from the British by the congress government. The Rs10,000 notes were the largest currency denomination ever printed by the Reserve Bank of India, introduced for the first time in 1938. All three notes were reintroduced in 1954. In the early '70s, the Wanchoo committee, a direct tax inquiry committee set up by the government, suggested demonetization as a measure to unearth and counter the spread of black money. However, the public nature of the recommendation sparked black money hoarders to act fast and rid themselves of high denominations before the government was able to clamp down on them, Mint reported. Then, in 1977, the Janata Party coalition government came into power. A year into the government's term, party leader Morarji Desai was more bullish about cracking down on counterfeits and black money. The High Denomination Bank Notes (Demonetisation) Act, instated by the ruling party on Jan. 16, 1978, deemed the Rs1,000, Rs5,000 and Rs10,000 notes illegal for the second time. At the time, then-RBI governor I.G. Patel disagreed with the measure and accused the Janata coalition government of trying to cripple the corrupt predecessor governments instead of simply eradicating black money. For the most part, Modi's measure mirrors Desai's-except this time, he has the backing of his RBI governor, Urjit Patel, who applauded Modi's "very bold step" addressing concerns about the "growing menace of fake Indian currency notes." But that doesn't mean all the sceptics are off his back. Economists doubt the impact of his decision. "That's because people don't stack black money in cash. Rather, they stash it in undisclosed accounts in Swiss Banks," said Abhiroop Sarkar, a 
professor at the Indian Statistical Institute. "So the demonetization won't affect the biggest fish."

\section{REASON FOR DEMONETISATION}

- Flushing out black money.

- Eliminate fake Indian currency notes (FICN).

- Strike at the root of financing of terrorism and left wing extremism.

- Convert non-formal economy into a formal economy to expand the tax base and employment.

- Give a big boost to the digitalisation of payments to make India a less cash economy.

\section{RESEARCH METHODOLOGY}

This study is of a descriptive nature. The study has been conducted to understand the level of cash transactions in the country and also to highlight different payment systems. This article tells about the meaning and reasons of demonetisation along with the sector-wise impact of demonetisation and positive and negative impacts of demonetisation on Indian economy.

Primary data are collected from respondents. Questionnaire method of 5 point scale is also used to collect the data from the respondents. Data is collected through random sampling technique.

Secondary data, which is collected from different secondary resources like newspaper, news websites, RBI report, magazines, research papers, Journals, other publications and some other literature review. The books have also been referred for theoretical information on the topic as required.

Simple pie charts and percentage has been used for analysis. To figure out the reliability and validity of the data, standard deviation and data skewness also checked. The research area is Thiruvananthapuram and the respondents are general public.

\section{REVIEW OF LITERATURE}

Kalyani, Pawan (2017) this paper studies the effects and shifting trends in marketing /purchasing to the alternative options available in the market. The data was collected by questionnaire method for better cognizing market situation. The result of the study show demonetization had both pros and cons. It is like refresh button in the Indian economy and flush all the dead deposited money into the economy, to the market through proper channels. It also helps the economy shift from cash to cash less transactions with the help of many e-wallet companies like Pay them and other source of online payments like mobile banking, online shopping, e-wallets, online banking, credit cards, debit cards, UPI etc.

Jagdeep singh, (2012) in this paper "Scenario of e-banking in today's life - A Survey" tells us about the constant and tremendous changes in the banking field due to the information technology. This study was conducted in Ludhiana city and the results revealed that respondents are aware of e-banking facilities and it has also increased the pace of transactions.

Abhani Dhara K. (2017) posits that this Demonetisation is proving to be more successful than the previous two. The era is changing. People are using online banking as a mode of payment. Bank employees are giving their best to make the demonetisation a successful one. Their support matters a lot. Though the demonetisation move has failed to grab the total black money in the economy, this has at least created fear in the minds of people holding black money. He concluded 
that demonetisation was a compulsory step to tackle the problem of black money, terrorism and corruption etc.

Preethi, S. \& Sangeetha, V.M. (2017) analysed the impact of demonetization on various sectors and the economy of the country. This study explores the reason of demonetization as these 1. Make India corruption free, 3 . Curb black money, 3. Controlling inflation, 4. Stop terror financing, 5. Make more people pay income tax 6. Make a cashless society and 7. Create Digital India. The conclusion of the study tells us demonetization policy is step of financial reform in the country. But it is a big decision, which has own its merits and demerits. These merits and demerits make a big effect on country business and economical activity.

Shanbhogue Girish, Kumar, A. Prashanth, Bhat, Swathi and Shettigar, Chethan (2016) defined currency ban as a move to stop counterfeit bank notes allegedly used for terror financing, as well as a surgical strike to black money and corruption in the country. Demonetisation leads to cash shortages in the country which proves detrimental to a number of small business, agriculture and transportation. The shortage of cash led to chaos and most people faced problems to exchange their banknotes due to the long queues outside banks and ATMs across the country. This demonetisation step was proved to be the biggest attack on black money and corruption in the history of Indian Economy and a movement toward digitalisation. It also encourages digital payments. They concluded that Demonetization is advantageous in short, medium and long-term.

Muthulakshmi, E.Kamatchi \& Kalaimani, G. (2017) describe how the tool of Demonetization can be used to eradicate parallel economy. Government addresses various issues with the help of Demonetization like black money, counterfeit currency, corruption, terrorism etc. The result of the study shows that government solves many problems with a single solution in the favour of reformed country. This policy is expected to cleanse the formal economic system and eliminate black money from the economy.

Manpreet Kaur (2017) in this paper “Demonetization: impact on cashless payment system” states the progressive shift to a cashless economy with greater focus on electronic transactions. Rising use of credit/debit cards, net banking and other online payment mechanisms will be another positive effect of demonetization, as these would not only lower transaction costs but some of these could help earn some fee income as well.

Uke, Lokesh (2017) analyses the positive and negative impact of note demonetization by Indian government. This study is based on secondary data, which is collected from newspapers, magazines, websites from the internet, some useful books related to topic etc. Here the author has utilized the opinions of experts on financial, economic fields and intellectual politicians. The result of the study showed that the Central government has taken a well-thought out and well-implemented step which would really eradicate all the existing black money from the market.?

Veerakumar, K. (2017) posits that the announcement of demonetization of 500 and 1000 currency notes by the government is a big shock to the citizen of India. The highest currency notes are withdrawn from the economy to counter the problem of tax evasion, counterfeit currency and financing of terror activities. It is shown that huge money is being deposited into the bank accounts which are more than specified limits and are subject to penalties and taxes. Usage of ewallets, debit and credit card has been increased tremendously and this will create a better cashless infrastructure.

P. Nandhini, Dr. G. Kalaimani, in this paper "Demonetization: impact on the economy" states that demonetization is necessary and has helped to deal with corruption. It has motivated cashless transactions. Basically, this paper throws light on the impact of demonetization on the economy. 


\section{FINDINGS OF THE PRESENT STUDY}

\section{Reasons for Demonetisation}

- Black Money: Demonetisation was a bold and revolutionary action taken by the government of India to curb black money and one that will have the deepest impact on the parallel economy in the country. Pockets and persons with black money can be identified with this move. A few businesses like property dealers, jewellers, foreign currency dealers, private money lenders generally hold huge amounts of unaccounted money in the form of currency notes. Such unaccounted money had created a parallel economy in the country. Such illegal money has reached the bank accounts through direct or indirect channels.

- To Hit the Fake Currency Rackets: Fake Currency Notes have been wasted by the demonetisation. Withdrawing highest currency notes out of the economy will have a serious impact on the fake currency syndicates, thus putting an end to the terror funding in Jammu and Kashmir, Naxalite hit states and North-eastern states. The fake currency with racketeers have been left in vain, and new currency notes with high security; making a counterfeit impossible. Demonetisation was a surgical attack on a fake currency circulating in the economy. Demonetization has converted those fake currency notes into a mere piece of papers.

- Online Transactions: The demonetization's motto was to encourage the cashless/digital economy. More and more cashless or less-cash transactions will lead to more disclosure of income which will increase the direct tax collections. With a reduction in cash transactions, alternative forms of payment will be more in demand. Electronic mode of payment like online transaction, payment through applications, E-wallets E-banking, usage of debit and credit cards etc. will surely see the substantial increase in demand

- To Hit Maoists: This step actually made money with Maoists worthless. As reported, Maoists had hoarded over Rs.7000 cores with them at Baster in Chhattisgarh. All such currencies are now nothing but pieces of papers

- Rise in GDP: Though demonetisation has negatively impacted sectors such as real estate and property, construction, and household consumption in general, it is believed that long-term benefits for GDP growth will outweigh the short-term transitional impact. We are now heading towards a 9\% GDP growth by FY2018-19.

\section{Position of Cash Transactions in India}

India is predominantly a cash-intensive economy. The payment system in India is in its development phase as cash is still the king in transactions. With rapid growth and modernization of the economy, India is going to embrace the new payment systems in the coming years. The cash intensity in India is very high compared to other developing countries. The value of notes and coins in circulation as a percentage of GDP for 2010 was $12.04 \%$ in India whereas it was just $3.93 \%$ in Brazil, 5.32\% in Mexico and 3.72\% in South Africa. The value of non-cash payment transactions compared to cash transactions is very less but there is a steady increase in the non-cash payments in the country. 


\section{Consumer Payment Statistics by Value (\% of Total)}

Table 1

\begin{tabular}{|l|c|c|c|c|c|c|}
\hline \multicolumn{1}{|c|}{ Payment Type } & $\mathbf{2 0 0 7}$ & $\mathbf{2 0 0 8}$ & $\mathbf{2 0 0 9}$ & $\mathbf{2 0 1 0}$ & $\mathbf{2 0 1 1}$ & $\mathbf{2 0 1 2}$ \\
\hline $\begin{array}{l}\text { Card Payment Transactions } \\
\text { (Excluding Commercial) }\end{array}$ & 2.8 & 3.1 & 2.9 & 2.8 & 3.5 & 4.1 \\
\hline Electronic Medium & 2.6 & 3.0 & 3.8 & 4.5 & 5.6 & 6.8 \\
\hline $\begin{array}{l}\text { Other Paper Transactions } \\
\text { (Checks, Demand Drafts) }\end{array}$ & 4.1 & 3.9 & 3.6 & 3.2 & 2.9 & 2.5 \\
\hline Cash Transactions & 90.6 & 90.0 & 89.7 & 89.5 & 87.9 & 86.6 \\
\hline
\end{tabular}

Source: Euromonitor Passport 2013

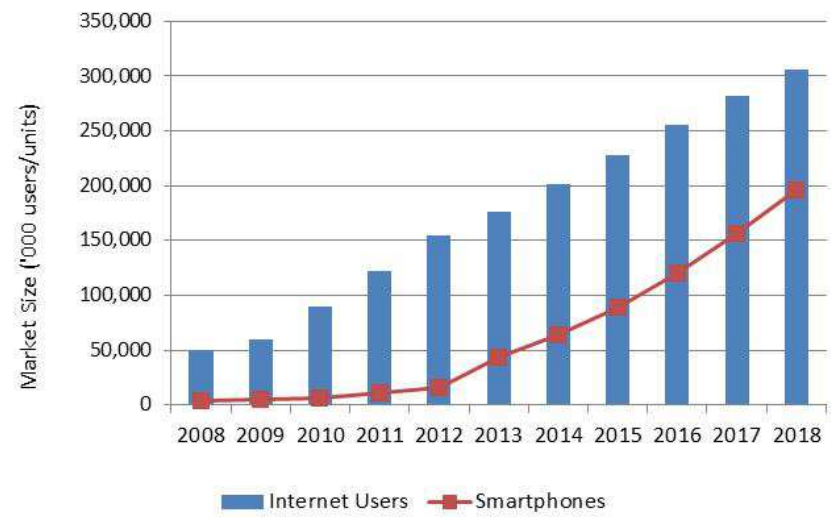

Figure 1

Consumer Payment Statistics by Volume (\%)

Table 2

\begin{tabular}{|l|c|c|c|c|c|c|}
\hline \multicolumn{1}{|c|}{ Payment Type } & $\mathbf{2 0 0 7}$ & $\mathbf{2 0 0 8}$ & $\mathbf{2 0 0 9}$ & $\mathbf{2 0 1 0}$ & $\mathbf{2 0 1 1}$ & $\mathbf{2 0 1 2}$ \\
\hline Card Payment & 0.32 & 0.38 & 0.42 & 0.45 & 0.51 & 0.60 \\
\hline Electronic Medium & 0.09 & 0.11 & 0.13 & 0.18 & 0.24 & 0.32 \\
\hline Other Paper Transactions & 0.27 & 0.26 & 0.25 & 0.25 & 0.24 & 0.24 \\
\hline Cash Transactions & 99.3 & 99.20 & 99.1 & 99.1 & 99.0 & 98.8 \\
\hline
\end{tabular}

Source: Euromonitor Passport 2013

The amount of money held in bills and coins (M0) relative to the amount held in demand deposit and savings accounts (M2) is a good indicator for comparing the cash intensity. M0 as a percentage of M2 is over $50 \%$ for India whereas it is just 24\% in Egypt, 9\% in Mexico and South Africa and 5\% in China (Mazotta, et.al 2014). The number of currency notes in circulation is also far higher than in other large economies. India had 76.47 billion currency notes in circulation in 2012-13 compared with 34.5 billion in the US.

\section{Position of Cashless Payments in India}

India has a competitive telecommunication market, well developed financial markets and it is a leading exporter of technology services. All these factors support the growth of cashless payments. But India has not gained much in terms of cashless payments compared to its peers. Non-cash payments in India are dominated by card payments, electronic direct transactions and non-cash paper transactions. Cards are the most used cashless payment options available in the country. The non-cash payments through modes of cheques, demand drafts, net banking and cards currently account for $22 \%$ of all consumer payments $\mathrm{n}$ India and it is projected to increase to $59 \%$ by 2025. 
Digital transactions showed steady growth of 50\% year-on-year over the last few years in India. And ATM transactions grew at $15 \%$ and branch-based transactions have reduced by $7 \%$ in FY 15 compared to FY14 (Alpesh, et.al).

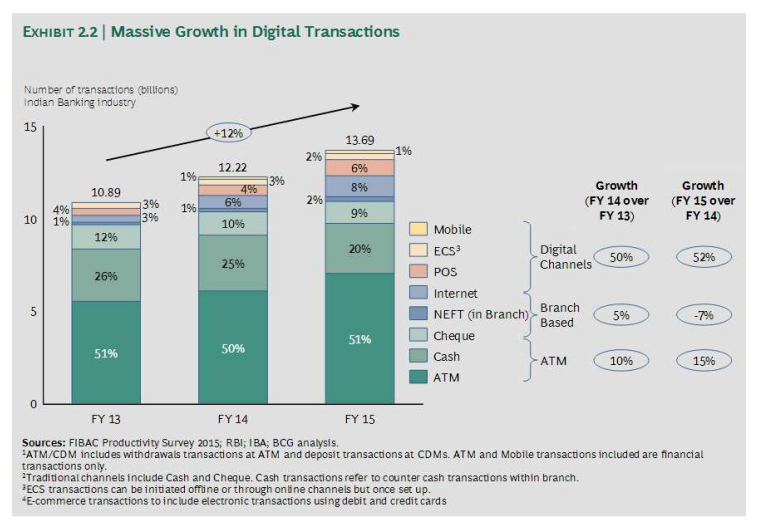

Figure 2

The digital transactions are continuously rising due to improvement in the smart phone penetration, good internet connection and support from the central bank towards digitization and they are going to change the payment scenario in the country.

\begin{tabular}{|c|c|c|c|c|c|}
\hline \multirow{3}{*}{$\begin{array}{l}\text { Month (2017) } \\
\text { April }\end{array}$} & \multirow{3}{*}{$\begin{array}{l}\begin{array}{l}\text { No. of digital } \\
\text { transactions }\end{array} \\
909.6\end{array}$} & \multirow{3}{*}{\begin{tabular}{|l|}
$\begin{array}{l}\text { No. of Pos } \\
\text { terminals }\end{array}$ \\
2.61 \\
\end{tabular}} & \multirow{3}{*}{$\begin{array}{c}\begin{array}{l}\text { No. of UPI } \\
\text { transactions }\end{array} \\
7\end{array}$} & & \\
\hline & & & & transadtions & $\begin{array}{l}\text { No. or creact, debilt } \\
\text { ard transactions }\end{array}$ \\
\hline & & & & 89.2 & 231.1 \\
\hline May & 926.55 & 2.69 & 9.16 & 91.3 & 233.4 \\
\hline June & 920.2 & 2.77 & 10.15 & 84.7 & 232.4 \\
\hline July & 938 & 2.84 & 11.44 & 88.7 & 237.6 \\
\hline August & 964.4 & 2.88 & 16.6 & 89.7 & 243 \\
\hline September & 958.6 & 2.9 & 30.7 & 87.5 & 240.3 \\
\hline October & 1048.3 & 2.95 & 76.7 & 96.2 & 255.7 \\
\hline November & 1081.58 & 2.99 & 104.8 & 92.8 & 244.6 \\
\hline December & 1150.28 & NA & 145.4 & 99.1 & 263.9 \\
\hline
\end{tabular}

\section{Figure 3}

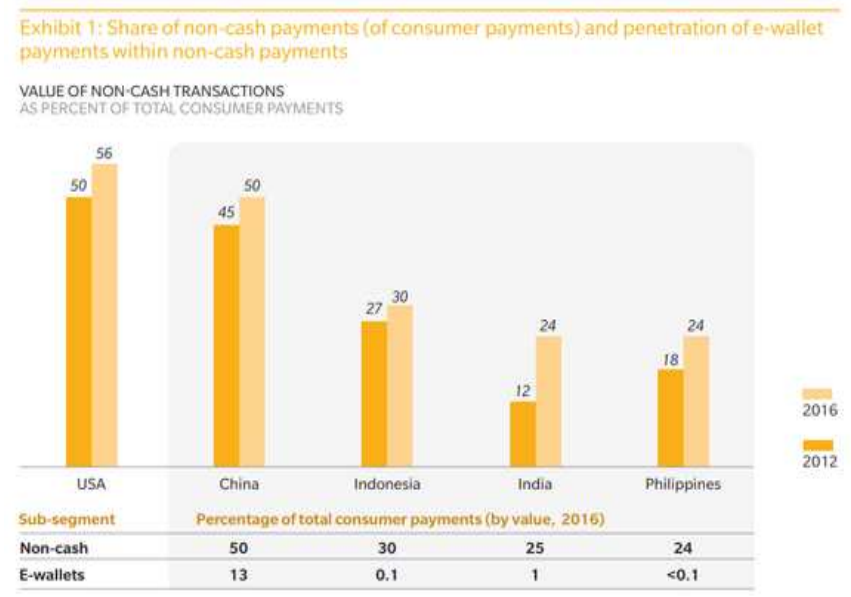

Figure 4 


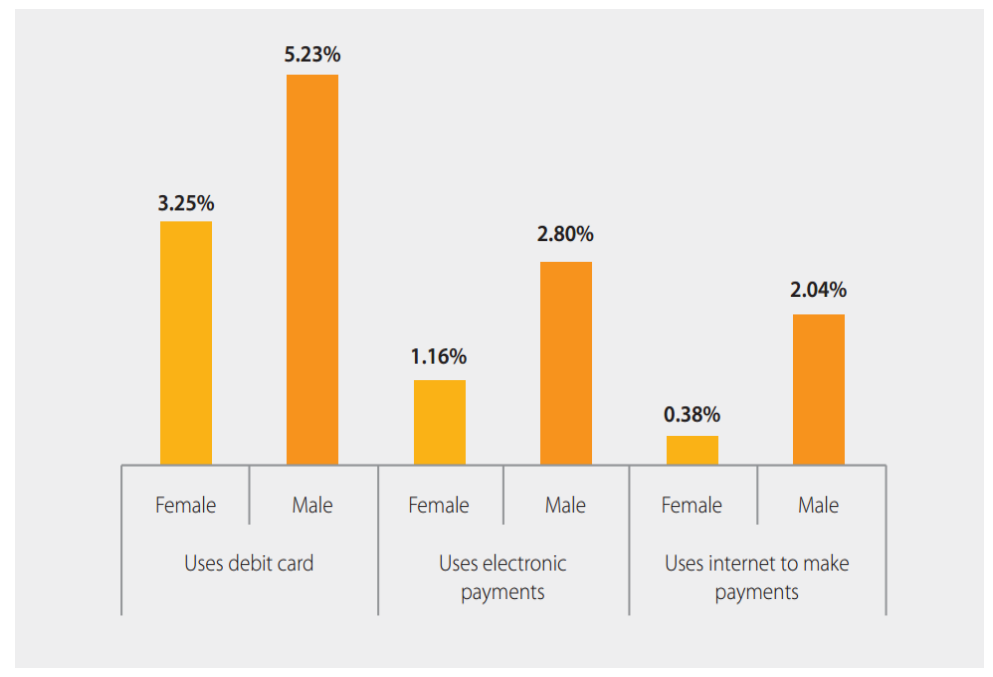

Figure 5

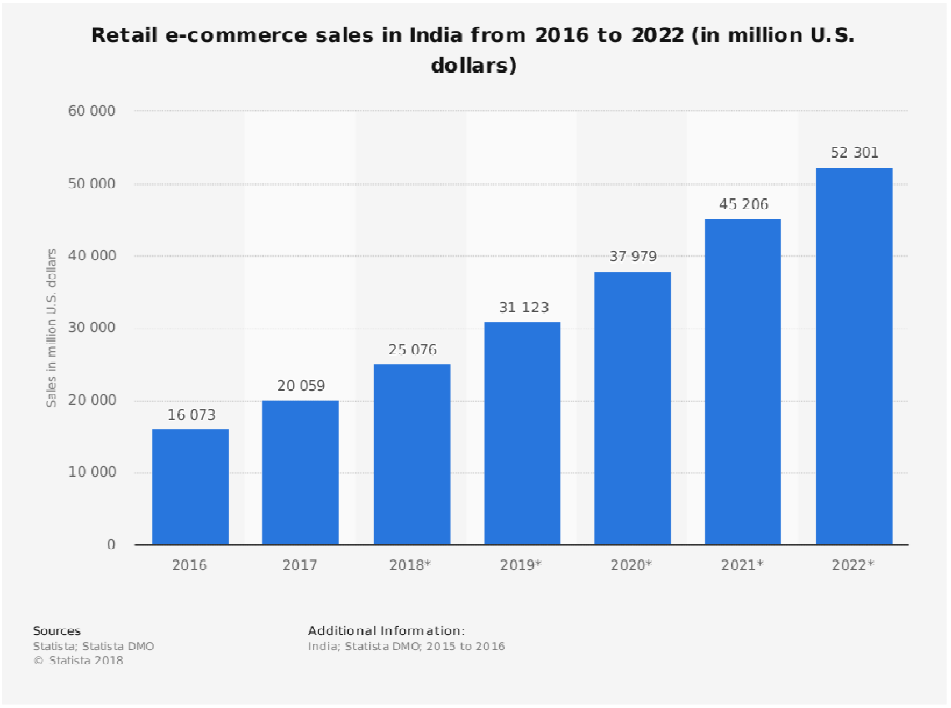

Figure 6

\section{Effects of Demonetisation}

Demonetization affects every field of life like social field, economic, political and legal field, but its main effect is on economic and business activity of the country. Demonetization also has too much effect on e-commerce industry in India. These effects are positive as well as negative.

\section{NEGATIVE EFFECT ON E-COMMERCE}

Demonetization has negative effect on e-commerce. They are given below.

\section{Online Sales Sudden Go-Down}

Demonetization makes sudden a big effect on online sales. Because Indian customer mostly believed in cash transactions, $90 \%$ of Indian online sales based on cash transactions. Demonetization affected $86 \%$ currency of the country so people have very less cash for spending on online purchase. Online sales registered a sudden decline due to less cash, because purchasers have less cash so their first priority is for the essential things to fulfil their basic requirement rather than purchase of other things. It makes big effect on online sales. 


\section{Order Undelivered Increase}

India faced a cash crisis after demonetization. It resulted in more than $50 \%$ of online purchase orders undelivered after 8 November 2016 due to non-payment of cash on delivery (according to ET Tech report) and payment in old currency against cash payment by purchaser. These undelivered orders made loss for the companies due to logistics and packing cost accrued in sales process. E-commerce total sales went down by up to $70 \%$ during the demonetization time. (According to "AIOVA" all Indian online wander association Spokesperson).

\section{Online Purchase Order Reduction}

During cash crisis in Indian total no of individual purchase orders also decreased. These are the reason of online purchase reduction, First purchaser do not have enough cash for purchase. They have a small quantity of cash in hand, so that they keep cash for purchase of necessary goods to fulfil their basic requirements. Second black money is spent on luxury goods, entertainment \& leisure things like antiques, car, interior decorator, electronics, clothes and fashion, movies, exotic vacations, dining out and personal grooming at salon etc. Both the reasons have a big effect of online purchase order, due to which online purchase order reduces during demonetization.

\section{Suspension of COD Orders}

Indian customer believed in cash purchase. Indian $90 \%$ purchase and sales based on cash transaction. So that Indian customer preferred COD mode of payment for online purchase by $83 \%$ (according Nielsen's global connected consumer survey). These are reasons for the COD mode of payments preferred by Indian consumer 1 . Online fraud risk 2. Convenience 3. Familiarity 4. Less use of plastic money 5. Lack of trust in online payment. After demonetization \% COD order undelivered due to lack of cash for payment. Undelivered orders are unnecessary expense of the e-commerce company, so that companies take decisions on COD facility suspension up to $60 \%$ on online purchase for a short time. It created an adverse effect on online business.

\section{Sudden Change in Preference of Online Purchasing}

After demonetizations purchase preference of Indian consumer sudden change due to cash crisis in India because they have lesser cash in their hand for spending. The Indian consumer shift from luxury good to necessary good like online food order, kitchen items, grocery items and fruits \& vegetables etc. for fulfilling their basic requirements.

\section{Purchasing Power Affected}

During demonetization many people lost their jobs. Many people do not run their business properly and many are not very friendly with use of plastic money. Many do not have money in their hand due to all money deposited in bank. Many people do not have debit card, credit card and net banking facility on their accounts. So they have money in their bank accounts but do not have any option of use. It had a huge impact on purchasing power of Indian customer due to demagnetization. Lower purchasing power adversely affected e-commerce sales.

\section{Sales of Luxurious Goods Affected}

Indian consumer spends most of their black money on luxury goods like expensive watches, clothes, cosmetics product home appliances etc. Demonetization throw-out whole black money from the circulation in the economy. Now back money is totally out of trend and due to this reason they lose their purchasing power with regard to luxury goods. Sales of luxury good through E-commerce declined during this period due to low purchasing power. 


\section{POSITIVE EFFECT ON E-COMMERCE}

Demonetization makes positive effect on e-commerce industry in India. These effects are given below.

\section{Online Web Traffic Increases}

Online traffic increase on online payments sites. NITI Aayog published a report on the growth of digital payments in India post-demonetization. According to this report, digital payments have seen a whopping surge of 271 per cent in the very first month following demonetization. The number of mobile wallet transactions has increased to 63 lakhs from 17 lakhs. Paytm, one among the biggest players in the mobile wallet space revealed that it served 45 million customers within 3 weeks after demonetization. Transactions via RuPay cards have also increased suggesting that more Jan-Dhan account holders have started using debit cards for online transactions. "We saw an initial decline in transactions for the 1 st 10 days of demonetization; however the transactions started getting back to normal from 1st week of December. As of February, we see a steady increase in transactions as well as online payments" as mentioned by Vikash Khetan, Founder Of Couponz Guru (A coupons and deals aggregator in India)

\section{Increase in Purchase of Essential Good}

Sales of essential goods like Grocery and food delivery set-ups increase because they sell essential items. Online orders by new customer go up to $25 \%$, from the usual $15-16 \%$. Total online food ordering increased between 40 to $50 \%$ during the November to January (according business world 9, Feb. 2017).

\section{Online Payment Option Repaid Increase}

Indian faces cash crises in India after the demonetization because they do not have cash in hand for purchase and payment. They had money in their banks so that they go for online payment with online payments options like pay tm, credit/ debit card, online banking, MIPS, NEFT, UPI \& other e-payment options. Due to this reason online option repaid increase. After 8 November Transaction through card Growth of more than $300 \%$ in terms of number \& more than $500 \%$ in terms of value of transaction. Transaction through mobile wallets Growth was more than $200 \%$ in terms of number and value of the transaction. Source (RBI).

\section{E-Transaction Increase in Small Town}

Demonetization makes big effect on small tier $2 \& 3$ class city's /town's online payment habit. Tier 2 city online transaction increased by $150 \%$ and tier 3 online transaction increases by $157 \%$ (Innovate payment solutions CEO 2017). They shift from cash to online payment for purchase and payment purpose. Its increase online business and profit in long term.

\section{Online Payment Increase}

Demonetization big aim to push customer towards making digital payments. People do not have cash in hand so that they move from cash to online payment options due to this reason digital payment transaction registered rapid increase day by day after 8 Nov 2016. In Transaction through card, there was a growth of more than $300 \%$ in terms of number $\&$ more than $500 \%$ in terms of value of transaction. Growth was more than $200 \%$ in terms of number and value of transactions in case of transaction through mobile wallets. Transaction on e-wallets have increased from 17 lakh to 63 lakh per day and use of Rupay card increased from 3.85lakh to 16 lakh per day (Times of India business Dec 9, 2016). Indian online total digital transactions increased 400-1000\% after the demonetization (government of India). 


\section{Digital Payment Growth Rates Following Demonetization}

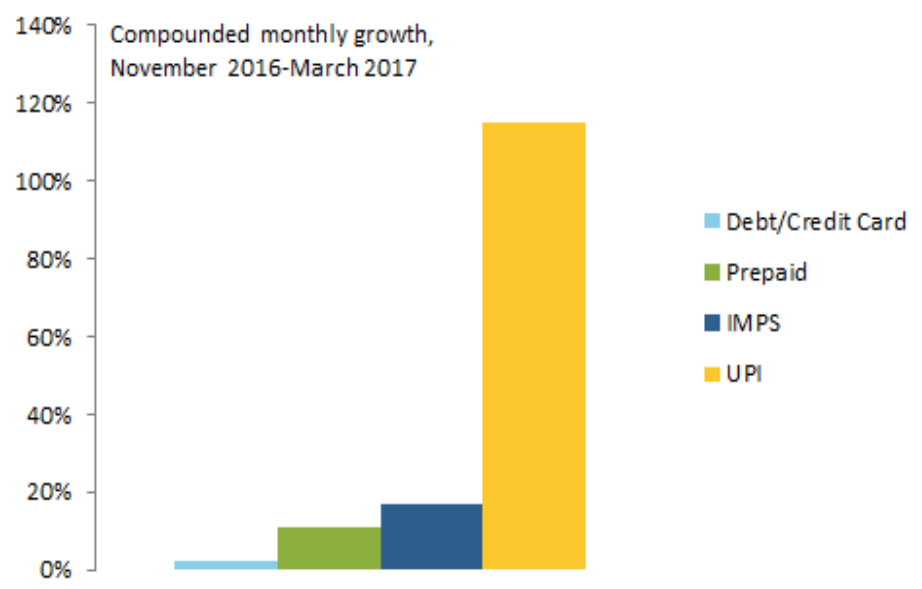

Source: Reserve Bank of India

Figure 7

\section{Government Promotion for Online Transactions}

Government of India promotes for online payment. Our respected prime minister of India promote payments through paytm, Exactly 30 days after junking existing high-value Rs500 and Rs1,000 banknotes, Union finance minister Arun Jaitley sought to draw Indians toward digital payments by offering up to $10 \%$ off on insurance policies, highway usage and concessions on train travel. The government will also waive service tax on online transactions below Rs. 2,000 (\$29.6), he added. Apart from these, there will be a $0.75 \%$ discount at petrol stations even though oil companies have currently added a surcharge for using debit or credit cards.

\section{Private Partners Promote Online Payment}

Many online options available for payments. They give lots of discount for online payments like HDFC bank, axis bank credit card, SBI credit card, Paytm discount on utility bill payments, recharge it now give discount for online different-2 bill payment and Coupon Dunia give discount coupon for online purchase etc.

\section{Increase in Bank Deposits}

Indian nationalized as well as private bank deposits suddenly increased after demonetization. Cash deposits totalling 1.6-1.7 lakh crore was made during the demonetization period ("demonetization and banking growth" Research article posted on RBI website) total aggregate deposited grew by $14.5 \%$ during November 11 to December 30,2016 as against 10.3\% during the corresponding period of 2015 (demonetization and banking growth” Research article posted on RBI website)

\section{Income Tax}

Demonetization makes positive effect on income tax returns. The number of returns filed increased by $24.7 \%$ as compared to previous year growth rate of $9.9 \%$ (according to Central Board of Direct Taxes) and personal advance income tax collections grew by 41 per cent as on 5 august 2017 ( according to finance minister). Personal Income Tax under Self-Assessment Tax (SAT) increased to 34.25\% over the corresponding period in F.Y. 2016-2017. 
Examination of the Payment Habits among Customer After Demonetisation

Information about Comfort Level with Technology

Table 3

\begin{tabular}{|c|l|c|}
\hline Sl. No & Particulars & \% of Respondents \\
\hline 1 & Very High & 45 \\
\hline 2 & High & 20 \\
\hline 3 & Medium & 10 \\
\hline 4 & Low & 5 \\
\hline 5 & Very Low & 20 \\
\hline Total & 100 \\
\hline Standard deviation & 15.41103501 \\
\hline Median & 20 \\
\hline Skewness & 1.28069543 \\
\hline
\end{tabular}

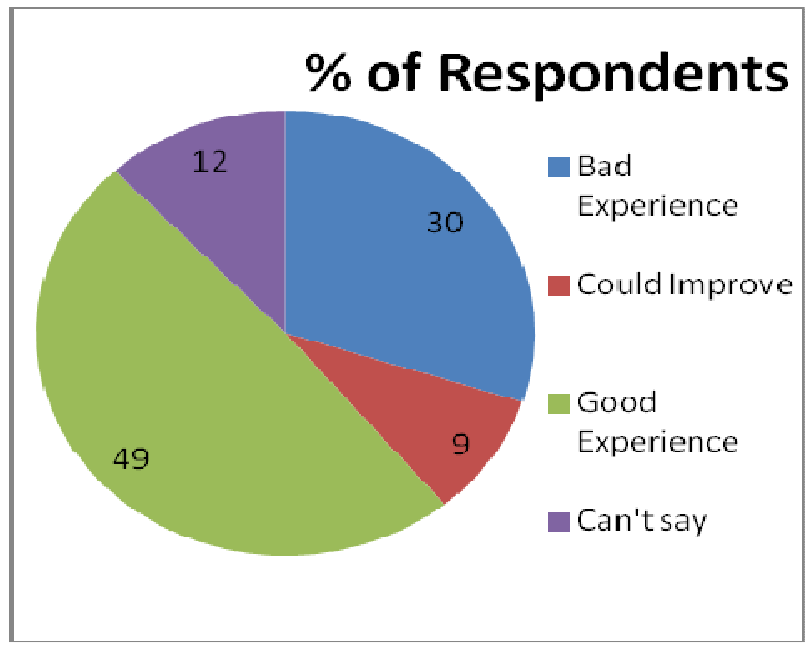

Figure 8

The above chart gives information about the comfort level with technology. It can be concluded that $45 \%$ respondents have a very high comfort with technology and $20 \%$ have high comfort. On the other hand $20 \%$ respondents have very low comfort with new technology.

Information about Usage of Payment Services by People

Table 4

\begin{tabular}{|c|l|c|}
\hline Sl. No & Particulars & \% of Respondents \\
\hline 1 & Credit card & 5 \\
\hline 2 & Debit card & 50 \\
\hline 3 & Coupons & 5 \\
\hline 4 & Net Banking & 10 \\
\hline 5 & Mobile Banking & 30 \\
\hline Total & 100 \\
\hline Standard deviation & 19.68501969 \\
\hline Median & 10 \\
\hline Skewness & 1.106130138 \\
\hline
\end{tabular}




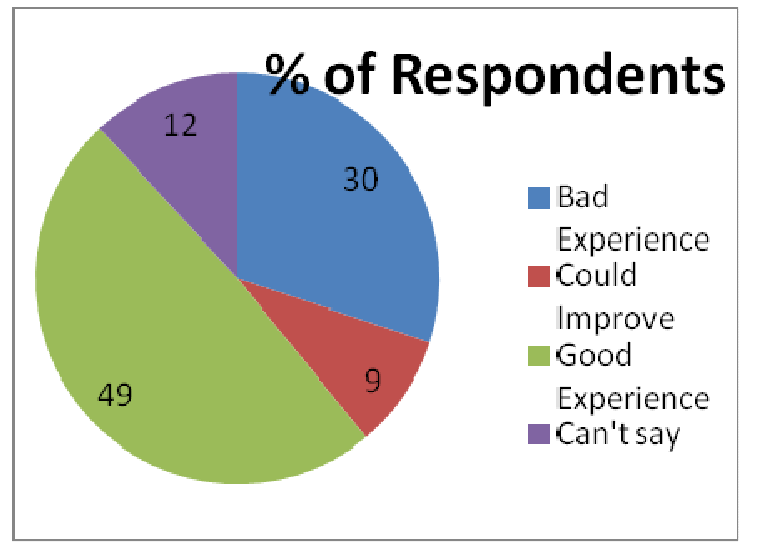

Figure 9

This chart shows the information about usage of payment services by people. So this can be concluded that most of the $(50 \%)$ respondents use a debit card while making payments, another major contribution to payment system is done by mobile banking and net banking ie of $30 \%$ and $10 \%$ respectively. The least used mode of payment is through coupons and credit cards.

Information about Usage of Cash, Cheque, ATM, Credit Card and Paytm by People

Table 5

\begin{tabular}{|c|l|c|}
\hline Sl. No & Particulars & \% of Respondents \\
\hline 1 & Credit card & 2 \\
\hline 2 & ATM & 40 \\
\hline 3 & Cash & 30 \\
\hline 4 & Cheque & 20 \\
\hline 5 & Pay Tm & 8 \\
\hline Total & 100 \\
\hline Standard deviation & 15.55634919 \\
\hline Median & 20 \\
\hline Skewness & 0.159377937 \\
\hline
\end{tabular}

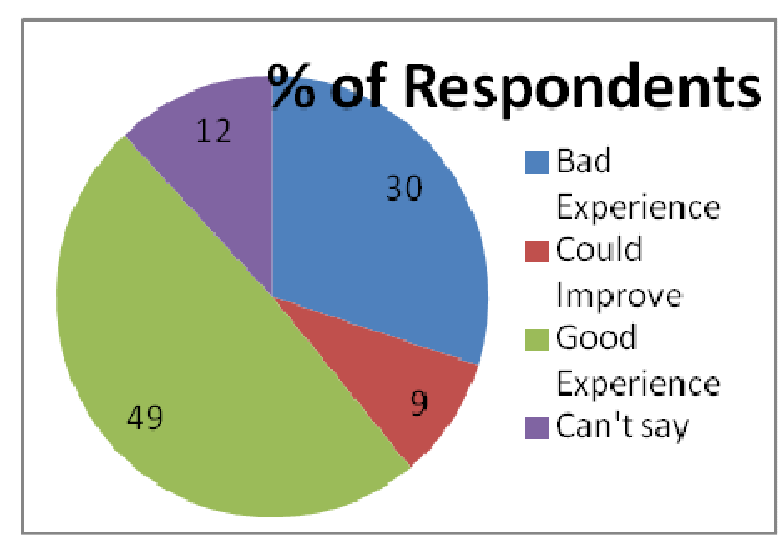

Figure 10

By analysing the above data we concluded that most of the respondents (40\%) are using ATM card while buying goods and services and $2 \%$ users are using credit cards for their purchase and service activity. 


\section{Information about the Implementation of Currency Ban by the Government}

Table 6

\begin{tabular}{|c|l|c|}
\hline Sl. No & \multicolumn{1}{|c|}{ Particulars } & \% of Respondents \\
\hline 1 & Bad Experience & 30 \\
\hline 2 & Could Improve & 9 \\
\hline 3 & Good Experience & 49 \\
\hline 4 & Can't say & 12 \\
\hline Total & 100 \\
\hline Standard deviation & 18.49324201 \\
\hline Median & 21 \\
\hline Skewness & 0.806996231 \\
\hline
\end{tabular}

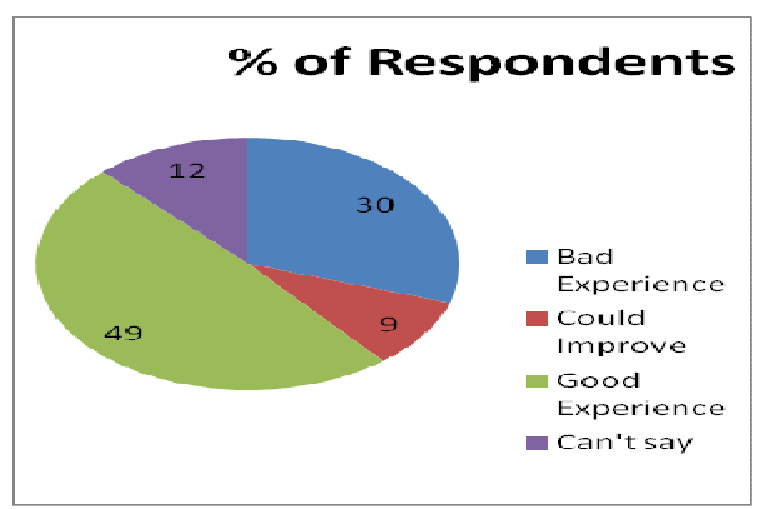

Figure 11

It gives information about experience of respondents regarding implementation of currency ban by the government. $49 \%$ say that it was a good experience to reduce corruption and other issues.

\section{CONCLUSIONS}

The move by the government to demonetise old currency and to replace it with the new one has taken the country by surprise. The move was an effort to handle the threat of illegal money, corruption, terror funding and counterfeit currency. The decision regarding demonetising the old currency was a step to eradicate the undeclared money from Indian economy. Demonetization has opened many inroads in the digital payment system in India. People are now becoming less apprehensive of technology, and are becoming comfortable with the digital world with every passing day. It may be a move towards the cashless economy. The demonetisation has introduced a new method or style of the cashless payments in the country. The new age banks are expected to give further improvements in the area of digital currency transactions. The technological advancements and innovative payment systems are going to reduce the cash transaction system in the future. The demonetisation had a big effect on e-commerce area. After demonetisation online business sales decreased, but after a few months it again increased slowly because the customers have started using their ATM debit cards and mobile wallets for transactions. Government and private payment service providers give big discounts on the use of online bill payments and purchase transactions. These types of discounts and offers create positive effects on e-commerce business and in India, e-commerce business will increase day by day. The present study focused on implementation of demonetization and its effect on digital payment. From the study, it can be concluded that the move of demonetization could have been improved by proper planning. In the nutshell, it can be said that demonetization has improved the quality of life of a common man with regard to digital payment system. 


\section{REFERENCES}

1. Shukla, Mansi (2017). Impact of digitalization in economy and the effects of demonetization: an overview, ELK Asia Pacific Journals -978-93-85537-02-8

2. Amato-McCoy, D. (2005). Creating virtual value, Bank Systems and Technology, Vol.1,pp 22-27.

3. Uke, Lokesh (2017). Demonetization and its effects in India, SSRG, International Journal of Economics and Management Studies (SSRG-IJEMS), Volume 4 issue2 Page 18

4. Shanbhogue, G. Kumar, A. P., Bhat, S. \& Shettigar, C. (2016). A Study On Demonetization of 500 And 1000 Rupee Notes \& Its Impact On the Various Sectors and Economy. International Journal of Research in Economics and Social Sciences.6(12). 274284.

5. Srija, A. (2017). The Demonetization Exercise Is A Move Towards Making India A 'Less Cash' Economy, cover story of Communiqué.

6. Nandhini.P, Kalaimani. Dr G, Demonetization: impact on the economy, IOSR Journal of humanities and Social Science (IOSR-JHSS) e-ISSN: 2279-0837, p-ISSN: 2279-0845. PP 31-33

7. Rahul Parkash Deodhar (November 2017). Black Money and Demonetization, International Journal of Advanced Educational Research, Volume 2; Issue 6;; Page No. 412-414

8. Kalyani, Pawan (2016). An Empirical Study of the Effects of Demonetization in India in the Year 2016 and Analyzing Shifting Trends in Marketing /Purchasing to The Alternative Options. Journal of Management Engineering and Information Technology (JMEIT), Volume -3, Issue-6

9. Siddiqui. Anam Siddiqui, Qureshi. Dr. Riyazuddin, Big Data In Banking: Opportunities and Challenges Post Demonetisation in India, IOSR Journal of Computer Engineering, PP 33-39

10. Singhal. Shweta (2017). Demonetization and E-banking in India, International Journal of New Technology and Research, Volume-3, Issue-1, Pages 20-25.

11. https://achieve.usbank.com/my-money/5-benefits-of-paying-bills-online/ Date accessed: 23/10/2017 5 Benefits of Paying Bills Online

12. Savadam Balaji \& H. Khan(2017). Demonetization and Improving Security in Money Transactions using Smart Cards and GSM Technologies. International Journal of Electronics, Communication \& Instrumentation Engineering Research and Development (IJECIERD). 7(1). 1-8

13. Abhani, D. K. (2017). A Study On Impact of Demonetization Over The Banking Sectorwith Reference To Veraval City. International Journal of Marketing \& Financial Management. 5(3). 21-26.

14. https://wealthhow.com/disadvantages-of-electronic-payment-systems/ Date accessed: 23/10/2017 Be aware of the disadvantages of the electronic payment systems

15. Veerakumar, K. (2017). A Study on People Impact on Demonetization. International Journal of Interdisciplinary Research in Arts and Humanities (IJIRAH), Vol. 2, Issue1.

16. Preethi, S. \& Sangeetha, V. M. (2016). Impact of Demonetization on Indian Economy, International Journal of Research in Economics and Social Sciences (IJRESS), Vol. 7 Issue 3, March-2017, pp. 20 28

17. Manpreet Kaur (2017) in this paper "Demonetization: impact on cashless payment system"

18. https://www.hotspotshield.com/resources/digital-wallet-security-concerns/ Date accessed: 24/10/2017 How safe is the digital 
wallet on your smartphone?

19. Roy, S., \& Sinha, I. (2014). Determinants of Customers' Acceptance of Electronic Payment System in Indian Banking Sector-A Study. International Journal of Scientific and Engineering Research, 5(1), 177-187

20. https://economictimes.indiatimes.com/wealth/invest/post-demonetisation-which-digital-payment-method-to-use-heres-how-tochoose/articleshow/Postde-monetization, which digital payment method to use? Here's how to choose

21. Kumar, P. (2015). An analysis of growth pattern of cashless transaction system. sep, 3(9), 37-44.

22. Muthulakshmi, E.K. and. Kalaimani, G. (2017). Impact of Demonetization on Indian Economy. IOSR Journal of Humanities and Social Science (IOSR-JHSS), PP 50-54.

23. Uke, Lokesh (2017). Demonetization and its effects in India, SSRG, International Journal of Economics and Management Studies (SSRG-IJEMS), Volume 4 issue2 Page 18

24. Singh. Jagdeep, (2012). Scenerio of E-banking in today's life-A survey, International Journal of computing and business research. 